\title{
Extent of implementation of service-learning in five Jesuit Universities in the Philippines
}

\author{
J.Q. Dalagan, M. Obedencio, L. Labitad. Xavier University, Philippines
}

A. Garciano, A. Urduja, G. Adarlo. Ateneo de Manila University, Philippines

L. Arcena, A. Sagaral, D. Abo-abo. Ateneo de Davao University, Philippines

M. Besenio, R. Ramos, F.M. Nubla. Ateneo de Naga University, Philippines

R. Austero, M. Emmanuel. Ateneo de Zamboanga University, Philippines

\section{Abstract}

Service-learning is a form of experiential education in which students engage in activities that address human and community needs together with structured opportunities intentionally designed to promote student learning and development. Philippine Higher Education Institutions (HEIs) are making attempts to integrate service-learning in their educational systems. In this current qualitative study, the mechanism of service learning in 5 Jesuit higher education institutions located in different regions in the Philippines was described. Furco's Self-Assessment Rubric for institutionalization of service learning as a framework was used as the evaluation tool. Results revealed that even if the institutions studied were all Jesuit universities, each one exhibited unique experiences and different levels of implementation of service learning. They also vary in the mechanism or approach of implementation. What was evident among the five Jesuit higher education institutions is their shared commitment towards service and social justice as part of their mission and identity. The difference in the level of implementation among the five HEIs depends on the longevity of the service learning in the institution, the number of programs that utilize service learning as a pedagogy, sustained commitment and persistence of the administrators, faculty and staff.

\section{Keywords}

Rubric, experiential learning, institutional support, quality, stage.

Fecha de recepción: 24/XI/2021

Fecha de aceptación: 9/XII/2021

\footnotetext{
Dalagan, J.Q. , Obedencio, M., Labitad, L., Garciano, A., Urduja, A., Adarlo, G., Arcena, L., Sagaral, A. Abo-abo, D., Besenio, M., Ramos, R., Nubla, F.M., Austero, R., y Emmanuel, M. (2021). Extent of implementation of service-learning in five Jesuit Universities in the Philippines. RIDAS, Revista Iberoamericana de Aprendizaje Servicio, 12, 71-79. DOI10.1344/RIDAS2021.12.8
} 


\section{Alcance de la implementación del aprendizaje-servicio en cinco universidades jesuitas en Filipinas}

\section{Resumen}

El aprendizaje-servicio es una forma de educación experiencial en la que los estudiantes participan en actividades que abordan las necesidades humanas y de la comunidad junto con oportunidades estructuradas diseñadas intencionalmente para promover el aprendizaje y el desarrollo de los estudiantes. Las Instituciones de Educación Superior de Filipinas (IES) están intentando integrar el aprendizaje-servicio en sus sistemas educativos. En este estudio cualitativo, se describió el mecanismo de aprendizaje-servicio en 5 instituciones jesuitas de educación superior ubicadas en diferentes regiones de Filipinas. La rúbrica de autoevaluación de Furco para la institucionalización del aprendizaje-servicio se utilizó como herramienta de evaluación. Los resultados revelaron que incluso cuando las instituciones estudiadas eran todas universidades jesuitas, cada una exhibía experiencias únicas y diferentes niveles de implementación del aprendizaje-servicio. También varían en el mecanismo o enfoque de implementación. Lo que fue evidente entre las cinco instituciones jesuitas de educación superior fue su compromiso compartido con el servicio y la justicia social como parte de su misión e identidad. La diferencia en el nivel de implementación entre las cinco IES depende de la longevidad del aprendizaje-servicio en la institución, la cantidad de programas que utilizan el aprendizaje-servicio como pedagogía, el compromiso sostenido y la persistencia de los administradores, profesores y personal no académico.

\section{Palabras clave}

Rúbrica, aprendizaje experiencial, apoyo institucional, calidad, etapa. 


\title{
Grau d'implementació de l'aprenentatge servei a cinc universitats jesuïtes a les Filipines
}

\begin{abstract}
Resum
L'aprenentatge servei és una forma d'educació vivencial en la qual els estudiants participen en activitats que aborden les necessitats humanes i de la comunitat juntament amb oportunitats estructurades dissenyades intencionadament per promoure l'aprenentatge i el desenvolupament dels estudiants. Les institucions d'educació superior filipines estan fent intents d'integrar l'aprenentatge servei als seus sistemes educatius. En aquest estudi qualitatiu actual, es va descriure el mecanisme d'aprenentatge servei en 5 institucions d'educació superior jesuïtes ubicades a diferents regions de les Filipines. La rúbrica d'autoavaluació de Furco per a la institucionalització de l'aprenentatge servei es va utilitzar com a eina d'avaluació. Els resultats van revelar que encara que les institucions estudiades eren totes universitats jesuïtes, cadascuna mostrava experiències úniques i diferents nivells d'implementació de l'aprenentatge servei. També variaven en el mecanisme o enfocament d'implementació. El que era evident entre les cinc institucions d'educació superior jesuïtes és el seu compromís compartit amb el servei i la justícia social com a part de la seva missió i identitat. La diferència en el nivell d'implementació entre les cinc institucions depèn de la longevitat de l'aprenentatge servei a la institució, el nombre de programes que utilitzen l'aprenentatge servei com a pedagogia, el compromís sostingut i la persistència dels administradors, el professorat i el personal no acadèmic.
\end{abstract}

\section{Paraules clau}

Rúbrica, aprenentatge experiencial, recolzament institucional, qualitat, etapa. 


\section{Introduction}

Jesuit values, principles and Ignatian pedagogy are integral parts of the Jesuit education. Throughout the nearly 500-year commitment to quality education, Jesuit institutions have the ability to carefully choose and evaluate pedagogical techniques. This has resulted to an organized system of Jesuit education all over the world including the Philippines (Fleming, 1999). Jesuit Universities continue its tradition of educational excellence by further integrating service learning into the university curriculum as a pedagogical tool. Service learning is found to be consistent and aligned with Ignatian Spirituality and the Jesuit mission in each higher education.

On the other hand, Philippine Higher Education Institutions (HEIs) are making attempts to integrate servicelearning in the curriculum, and they are generally focused on education, general health and socio-economic wellbeing and livelihood. Mandated by the Philippine government, the National Service Training Program (NSTP) which was promulgated through Republic Act No. 9163 in 2001 and implemented in 2002 is considered as an experiential learning course that enhances civic consciousness and defense preparedness among higher education students. Different HEIs have varying degrees of implementation of community engagement which may or may not be integrated into the curriculum. Service-learning is usually confused with community service, volunteering, practicum and other kinds

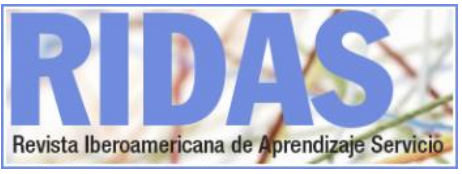

of non-classroom-based learning experiences. Service-learning is a method of teaching in which students are given the opportunity to engage and actively participate in service experiences in the community. These activities are integrated into the academic curriculum and students are provided time for personal reflection. To date, there are limited research done to investigate the extent of institutionalization of service-learning in the Philippines.

Thus, this study is the first attempt to describe service-learning implementation in Philippine Jesuit Higher education institutions using Furco's Self-Assessment Rubric for institutionalization of service learning as a theoretical framework. Andrew Furco's tool is frequently used in evaluating the extent of implementation of service-learning in higher education. This was first published in 1998 and was primarily used to help higher education community in assessing their progress towards institutionalization of service-learning. Furco's instrument has been adapted and implemented at a global level. There are studies done on institutionalization of service-learning using Furco's tool in the Universities in Europe and the US. Heras et al. (2017) reported the degree in which servicelearning has been established at Spanish Universities using Furco's rubric. Lewing and Shehane (2017) determined the level of service-learning institutionalization within the faithbased, faith-affiliated and secular institutions of the Gulf coast region of the United States using Furco's selfassessment rubric.

Dalagan, J.Q. , Obedencio, M., Labitad, L., Garciano, A., Urduja, A., Adarlo, G., Arcena, L., Sagaral, A., Abo-abo, D., Besenio, M., Ramos, R., Nubla, F.M., Austero, R., y Emmanuel, M. (2021). Extent of implementation of service-learning in five Jesuit Universities in the Philippines. RIDAS, Revista Iberoamericana de Aprendizaje Servicio, 12, 71-79. DOI10.1344/RIDAS2021.12.8 
Furco's rubric consists of five dimensions with a set of components that characterize the dimension. The following are the dimensions: (1) Philosophy and Mission of Service Learning; (2) Faculty Support for and Involvement in Service-Learning; (3) Student Support for and Involvement in Service-Learning; (4) Community Participation; (5) Institutional Support for Service-learning. Furco also identifies 3 stages or levels of development. Stage One is the critical mass building stage where universities begin to recognize service-learning and they are making efforts for university faculty and staff to appreciate servicelearning. Stage two is the quality building stage in which the universities are focused on the development of quality service-learning activities. Stage three is the sustained institutionalization stage where the campus has fully institutionalized service-learning in the structure of the institution. Furco, however, did not prescribe the manner in which the goals are to be achieved in order to give institutions the space for cultural and organizational context (Furco, 2002).

The main focus of this research is dimension five which is on institutional support. All five dimensions of institutionalization in Furco's rubric are important. However, the institutional support for service-learning is found to be a critical aspect to ensure that service-learning is sustained as a meaningful part of the University's long -term interest. The dimension institutional support for service-learning has five components: coordinating entity, policy-making entity, staffing, funding, administrative support and evaluation and assessment.

\section{Methodology}

This qualitative research study utilized the multiple case study method to discover the extent of implementation of service-learning in the five Jesuit higher education institutions in the Philippines using Furco's Self-

Assessment Rubric for institutionalization of service learning as a framework. Three of these universities are located in the Southern part of the Philippines, one in Northern part and one in the National Capital region. Each university conducted focus group discussion (FGD) and key informant interviews (KII) among selected students, alumni, community members, faculty members and administrators. Guide questions for the FGD and KII were provided based on Furco's assessment instrument. Data collected from each university were compiled, examined and analyzed for similarities and differences in the service-learning implementation and based on the 5th dimension of Furco's which is Institutional Support for Service-learning. Universities involved in the study were coded A-E.

\section{Results and discussion}

The research teams per institution assessed their university's stage or level of institutional support for service learning. Table 1 showed the different stages of the five universities. Findings revealed that out of the five institutions, only University $E$ was found to be in the level of Sustained Institutionalization (Stage 3) in all the

Dalagan, J.Q. , Obedencio, M., Labitad, L., Garciano, A., Urduja, A., Adarlo, G., Arcena, L., Sagaral, A., Abo-abo, D., Besenio, M., Ramos, R., Nubla, F.M., Austero, R., y Emmanuel, M. (2021). Extent of implementation of service-learning in five Jesuit Universities in the Philippines. RIDAS, Revista Iberoamericana de Aprendizaje Servicio, 12, 71-79. DOI10.1344/RIDAS2021.12.8 
components of institutional support for service learning. All the other four universities are in the Quality building stage (Stage 2).

Table 1. Stage of Institutional Support for Service learning of each university according to Furco's rubric

\begin{tabular}{|c|c|c|c|c|c|c|}
\hline $\begin{array}{l}\text { UNI. } \\
\text { code }\end{array}$ & $\begin{array}{l}\text { coord. } \\
\text { entity }\end{array}$ & $\begin{array}{l}\text { policy- } \\
\text { making } \\
\text { entity }\end{array}$ & staffing & funding & $\begin{array}{l}\text { admin. } \\
\text { support }\end{array}$ & $\begin{array}{l}\text { evaluation } \\
\text { \& } \\
\text { assessment }\end{array}$ \\
\hline A & $\begin{array}{c}\text { STAGE } \\
2\end{array}$ & $\begin{array}{c}\text { STAGE } \\
\mathbf{3}\end{array}$ & $\begin{array}{c}\text { STAGE } \\
2\end{array}$ & $\begin{array}{c}\text { STAGE } \\
\mathbf{3}\end{array}$ & $\begin{array}{c}\text { STAGE } \\
3\end{array}$ & $\begin{array}{c}\text { STAGE } \\
\mathbf{2}\end{array}$ \\
\hline B & $\begin{array}{c}\text { STAGE } \\
2\end{array}$ & $\begin{array}{c}\text { STAGE } \\
2\end{array}$ & $\begin{array}{c}\text { STAGE } \\
1\end{array}$ & $\begin{array}{c}\text { STAGE } \\
\mathbf{3}\end{array}$ & $\begin{array}{c}\text { STAGE } \\
2\end{array}$ & $\begin{array}{c}\text { STAGE } \\
1\end{array}$ \\
\hline C & $\begin{array}{c}\text { STAGE } \\
\mathbf{3}\end{array}$ & $\begin{array}{c}\text { STAGE } \\
\mathbf{3}\end{array}$ & $\begin{array}{c}\text { STAGE } \\
\mathbf{2}\end{array}$ & $\begin{array}{c}\text { STAGE } \\
2\end{array}$ & $\begin{array}{c}\text { STAGE } \\
2\end{array}$ & $\begin{array}{c}\text { STAGE } \\
2\end{array}$ \\
\hline D & $\begin{array}{c}\text { STAGE } \\
2\end{array}$ & $\begin{array}{c}\text { STAGE } \\
\mathbf{3}\end{array}$ & $\begin{array}{c}\text { STAGE } \\
2\end{array}$ & $\begin{array}{c}\text { STAGE } \\
2\end{array}$ & $\begin{array}{c}\text { STAGE } \\
2\end{array}$ & $\begin{array}{c}\text { STAGE } \\
2\end{array}$ \\
\hline E & $\begin{array}{c}\text { STAGE } \\
\mathbf{3}\end{array}$ & $\begin{array}{c}\text { STAGE } \\
\mathbf{3}\end{array}$ & $\begin{array}{c}\text { STAGE } \\
\mathbf{3}\end{array}$ & $\begin{array}{c}\text { STAGE } \\
\mathbf{3}\end{array}$ & $\begin{array}{c}\text { STAGE } \\
3\end{array}$ & $\begin{array}{c}\text { STAGE } \\
\mathbf{3}\end{array}$ \\
\hline
\end{tabular}

Note: Stage 1-critical mass building Stage 2- quality building

Stage 3-sustained institutionalization

Source: own elaboration

A.1. Coordinating Entity: refers to an institution's committee or center that is primarily concerned in providing assistance in the execution, promotion, and institutionalization of servicelearning. According to Bringle and Hatcher (2000), having a centralized office that provides technical and logistical support is an important aspect of institutional infrastructure. Centralized office with full time staff that is supported with institutional funds is a manifestation of greater commitment by campus leadership that can be equated with greater institutionalization. In the coordinating entity component, three of the institutions being studied are in the quality building (stage 2) and two are in sustained institutionalization (stage 3 ). Key informant interviews and FGDs revealed that each university has already set up an office/center that takes care of service-learning (i.e., Arrupe Office of Social Formation [AOSF]), Office for Social Concern and Involvement [OSCI], Social Awareness on Community and Service Involvement [SACSI], The Center for Community Development [CCD], and social development [SD] Office). However, even with the establishment of the office/center, some of the universities reported that "The university is yet to set up a coordinating committee that would oversee the implementation, advancement, and institutionalization of service-learning. In a sense, the university has no coordinating entity. That's part of the deliverable of a teacher. ... that is part of the task of the teacher of the course". One university has a coordinator, but assignment is not dedicated to service-learning only, "Coordination for service learning is assigned to the Coordinator for Faculty Social Involvement. However, this coordinator also has responsibilities other than service learning". Out of the five universities, two have formators/coordinators who are working full-time for service-learning.

\section{A.2. Policy making entity: this} component refers to the institution's policy-making body that affirms service-learning as a significant educational goal for the campus. This entity develops and implements the

Dalagan, J.Q. , Obedencio, M., Labitad, L., Garciano, A., Urduja, A., Adarlo, G., Arcena, L., Sagaral, A., Abo-abo, D., Besenio, M., Ramos, R., Nubla, F.M., Austero, R., y Emmanuel, M. (2021). Extent of implementation of service-learning in five Jesuit Universities in the Philippines. RIDAS, Revista Iberoamericana de Aprendizaje Servicio, 12, 71-79. DOI10.1344/RIDAS2021.12.8 
service-learning policies. Four of the institutions identified their universities in the Sustained Institutionalization stage in the component of policy making entity. The unit that serves as policy making body differs from one university to another. University $E$ has the Vice President for academics while University $C$ has Vice President for social development. The universities through its policy making body had created significant guidelines and policies that greatly impact servicelearning implementation like teaching and reimbursement policies. One university reported that even if there is no standard policy yet (during the time of the interview), the university is seriously considering to craft servicelearning policies. This component is essential because a well-defined organizational structures for servicelearning implementation with policies and guidelines will facilitate the pedagogy's dissemination and stabilization.

\section{A.3. Staffing: this refers to a suitable} number of permanent staff members who understand and advocate servicelearning so that they can forward the advancement and institutionalization of service-service learning on campus. Staff in a centralized office helps in designing periodic strategic planning, conversations about service-learning in various forms, assistance to faculty, and scholarship on service-learning. Each of these functions is essential to support the other faculty members who are interested in developing servicelearning course. University $\mathrm{E}$ and $\mathrm{C}$ have full time staff who devote time to coordinate and manage the implementation of service-learning. On the other hand, University A has formators, but their work is not fully focused on service-learning. University $D$ and $B$ lack staff who work full time for service-learning.

\section{A.4. Funding: this component will determine the university's full commitment to service-learning. Three universities assessed themselves to be in the Sustained Institutionalization stage. There is clear budget allocation for service-learning as they indicated "Budget from the tuitions and fees are allocated to fund service-learning initiatives" (University A). Two universities are in the quality building stage and University D reported "And although the university has included a social involvement (SI) fee in the students' tuition to sustain social involvement and service-learning activities, this budget is not sufficient".}

\section{A.5. Administrative support: this component refers to the institution's administrative leaders who believe in service-learning as a pedagogy and fully support it. They actively promote service-learning as a visible and important part of the university. In the component on administrative support, 3 universities are in quality building stage and two are in the level of sustained institutionalization. The administrators are invested to make service learning a significant part of the university by conducting consultation, believing in its pedagogy and encouraging faculty. The universities imparted, "They (administrators) conduct consultation and ask us what we need in order to implement the plans. That is how the plan to do benchmarking came up.}

Dalagan, J.Q. , Obedencio, M., Labitad, L., Garciano, A., Urduja, A., Adarlo, G., Arcena, L., Sagaral, A., Abo-abo, D., Besenio, M., Ramos, R., Nubla, F.M., Austero, R., y Emmanuel, M. (2021). Extent of implementation of service-learning in five Jesuit Universities in the Philippines. RIDAS, Revista Iberoamericana de Aprendizaje Servicio, 12, 71-79. DOI10.1344/RIDAS2021.12.8 
They wanted to push for the implementation of service-learning" (University B). Another university reported, "The creation of the office of the VP for $S D$ is a manifestation of the admin support. The VP for Higher Ed encouraged the faculty to engage in service-learning through a memo" (University C). One university revealed, "The former Academic Vice President had this to say about institutional support: ... 'I was not looking for anybody to say', 'oh, he made the SLP happen in the university'. No. I wanted to be able to say, 'Now, we all made SLP happen'. And we will do it with or without official support because we believe it" (University $\mathrm{E}$ ). This shows a strong foundational commitment that service-learning is essential to the university's mission and vision. This provides an anchor to sustain servicelearning program (Schaffer, 2004).

\section{A.6. Evaluation and Assessment: this} component refers to mechanisms which are in place to promote the evaluation and assessment of the number and quality of service-learning taking place in the university. This will address issues on how sufficient, thorough, and comprehensive these mechanisms are. In the area of evaluation and assessment, most universities are either in the quality building stage or critical mass building. Universities shared "There are student evaluations about service learning, but these assessments are not systematic. Assessing community impact is lacking" (University A). Another university reported, "Basically, there is no formal or standard evaluation tool. Although we have which was done by the previous P.O., I only improve it" (University B).

\section{Conclusions}

Service-learning is a powerful pedagogical tool where students apply classroom learning to communities. For it to survive and thrive, service learning must be institutionalized. Results revealed that no two higher education institutions are similar in the manner of institutionalization of service-learning. Each varies in the level of institutional support for service learning. In this study, each university has its own service-learning structure but what is common among the five Jesuit universities is they each has an office/center that manages service learning, and they have a shared commitment towards their Ignatian identity, service and social justice. Factors that may have affected the difference in the level of implementation among the five HEIs are the following: the longevity of the service learning in the institution, the number of programs that utilize service learning as a pedagogy, and sustained commitment and persistence of the administrators, faculty and staff. Results demonstrated that funding, staffing and evaluation and assessment of service-learning were found to be a challenge among the institutions being studied.

\section{Acknowledgement}

Authors acknowledge the Philippines' Commission of Higher Education for the research grant.

Dalagan, J.Q. , Obedencio, M., Labitad, L., Garciano, A., Urduja, A., Adarlo, G., Arcena, L., Sagaral, A., Abo-abo, D., Besenio, M., Ramos, R., Nubla, F.M., Austero, R., y Emmanuel, M. (2021). Extent of implementation of service-learning in five Jesuit Universities in the Philippines. RIDAS, Revista Iberoamericana de Aprendizaje Servicio, 12, 71-79. DOI10.1344/RIDAS2021.12.8 


\section{References}

Bringle, R.G., \& Hatcher, J.A. (2000).

Institutionalization of service learning in higher education. The Journal of Higher Education, 71(3), 273-290.

https://doi.org/10.2307/2649291

Heras, R., Masgrau M., \& Soler, P. (2017). The institutionalization of service learning at Spanish universities. International Journal of Research on Service-learning and Community Engagement, 5(1), 2374-9466. https://dugidoc.udg.edu/handle/10256/14912

Fleming, J. (1999). The Emerging Role of Service Learning At Jesuit Universities. Service Learning, General. 1-6.

https://digitalcommons.unomaha.edu/c gi/viewcontent. cgi?article $=1083 \&$ contex $\underline{\mathrm{t}=\text { slceslgen }}$

Furco, A. (2002). Self-assessment rubric for the institutionalization of service-learning in higher education. Univeristy of California.

https://digitalcommons.unomaha.edu/c gi/viewcontent.cgi?article $=1105 \&$ contex $\underline{\mathrm{t}=\text { slcesigen }}$

Lewing, M., \& Shehane, M. (2017). The institutionalization of service-learning at the independent colleges and universities of the Gulf Coast region. Christian Higher Education, 16(4), 211231.

https://doi.org/10.1080/15363759.201 $\underline{6.1254074}$

Schaffer, R.H. (2004). Service-learning in Christian higher education: Bringing our mission to life. Christian Higher
Education, 3(2), 127-145. https://doi.org/10.1080/153637504904 29417 